\title{
Spectrophotometric Determination of Chlorpromazine Hydrochloride Using 4- Nitroanilline by Oxidative Coupling Reaction
}

\author{
Asmaa A. M. Al-rashidy* \\ Abdulrahman K.A.Al_Taiee \\ Mohannd Faisal Shareef
}

Received 15/2/2018, Accepted 13/12/2018, Published 17/3/2019

This work is licensed under a Creative Commons Attribution 4.0 International License.

\begin{abstract}
:
A simple, rapid spectrophotometric method has been established for the determination of chlorpromazine hydrochloride (CPZ) in its pure form and in a tablet formulations. The suggested method is based on the oxidative coupling reaction with4-nitroainlline using $\mathrm{KIO}_{3}$ in acidic solution to produce a violet colored product with maximum absorption at $\lambda=526 \mathrm{~nm}$. The analytical data obtained throughout this study could be summarid as follows: $1 \mathrm{ml}$ of $1 \mathrm{M} \mathrm{HCl}(\mathrm{pH}=2.2), 1 \mathrm{ml}$ of 4-nitroanilline $\left(1 \times 10^{-2} \mathrm{M}\right)$, and $1.5 \mathrm{ml}$ of $\left(1 \times 10^{-2}\right) \mathrm{KIO}_{3}$ per $25 \mathrm{ml}$ reaction medium. The order of additions, coupling reaction time, and temperature in addition to the type of solvent were studied.

The Beer's law is obeyed over the concentration range of $(5-40) \mu \mathrm{g} \mathrm{ml} l^{-1}$, but the detection limit and quantification limit are 0.34 besides $1.03 \mu \mathrm{g} \mathrm{ml}^{-1}$ respectively. The correlation coefficient ( $\mathrm{r}$ ) for the calibration graph was found to be 0.9980 , molar absorptivity of $10.25 \times 10^{3} \mathrm{~L}_{\mathrm{mol}}{ }^{-1} . \mathrm{cm}^{-1}$, and Sandell's sensitivity index of $0.03467 \mu \mathrm{g} . \mathrm{cm}^{-2}$. The precision and accuracy of the method were tested by calculating the percentage of relative standard deviation $(\mathrm{RSD} \%)(<1.831 \%)$ and the average recovery percent $(99.22 \%)$ average error percent $\mathrm{E}_{\mathrm{rel} \%}(0.558)$.

Direct and standard addition procedures were applied to both standards and specimens of pharmaceutical and the results indicate that the suggested method was successfully applied for the determination of CPZ.
\end{abstract}

Key words: Chlorpromazine Hydrochloride Determination, $\mathrm{KIO}_{3}$, 4-nitroanilline, Spectrophotometric.

\section{Introduction:}

Chlorpromazine Hydrochloried (CPZ) is the most important compound in the group of phenothiazine derivatives. CPZ is widely used as a healing agent for treating various psychological and personality illnesses (1-3). It is 3-(2-chloro-10H-phenothiazin-10yl)-N,N-dimethylpropan-1-aminehydrochloride $\mathrm{C}_{17} \mathrm{H}_{19} \mathrm{ClN}_{2} \mathrm{~S}$.HCl (Fig.1). Like other phenothiazine derivatives it contains heterogeneous rings containing sulfur and nitrogen atoms.<smiles>CN(C)CCCN1c2ccccc2Sc2ccc(Cl)cc21</smiles>

Figure 1. The structure of chlorpromazine hydrochloride.

Department of Chemistry, College of Education for pure sciences, University of Tikrit, Tikrit, Iraq.

"Corresponding author:asmamohahh@tu.edu.iq
A number of methods have been applied for the determination of chlorpromazine hydrochloride in pure and dosages. These include HPLC (4-5), liquid-mass spectroscopy (6), potentiometry (7-9), LC-MS/MS (10), GC (11), flow injection analysis (12-13), voltammetry (9), Among the spectrophotometric methods, several methods were proposed depending upon the oxidation of drug using various oxidizing agents (14-17).

In this work, a study of the spectrophotometric determination of $\mathrm{CPZ}-\mathrm{HCl}$ relying on the oxidative coupling of the drug with 4-nitroaniline using potassium iodate as oxidation reagent in acidic medium.

\section{Materials and Methods:}

T90 UV-Visible Spectrophotometer PG Instrumental Ltd, UK with $10 \mathrm{~mm}$ quartz cell was used for all spectrophotometric quantities, Jenway $3310 \mathrm{pH}$ meter was used to check the $\mathrm{pH}$ of solutions, and Sartorius Balance 210S kern was used to perform all weight measurements. 


\section{Reagents}

Fully chemicals used were of analytical grade and chlorpromazine. $\mathrm{HCl}$ typical material was provided from State Company for Drug Industries and Medical Appliance (SDI) SamarraIraq. Distilled water was used to prepare all solutions.

A $\left.1000 \mu \mathrm{g} / \mathrm{ml}\left(2.814 \times 10^{-3} \mathrm{M}\right)\right) \mathrm{CPZ}$ of solution was prepared by dissolving $0.100 \mathrm{gm}$ in $100 \mathrm{ml}$ distilled water and stored in dark and used, for at least one month, as stock solution. More dilute working solutions of the drug were prepared by serial dilutions with distilled water. 4-nitoanilline solution $\left(1.000 \times 10^{-2} \mathrm{M}\right)$ was freshly ready daily by dissolving $0.0345 \mathrm{gm}$ in $5 \mathrm{ml}$ ethanol and completed by distilled water to $25 \mathrm{ml}$, while the calculated weight of $\mathrm{KIO}_{3} \quad 0.2140 \mathrm{gm}$ dissolved in $100 \mathrm{ml}$ distilled water was required to prepare $\left(1.000 \times 10^{-2} \mathrm{M}\right)$ solution. $1.000 \times 10^{-1} \mathrm{M}$ solution of each of sodium hydroxide and hydrochloric acid was prepared and used.

\section{General procedure}

In a $25 \mathrm{ml}$ volumetric flask, $1 \mathrm{ml}$ of $1.000 \times 10^{-2}$ M 4-nitroanilline $(\mathrm{R})$ solution is mixed with 1.500 $\mathrm{ml}$ of $1.000 \times 10^{-2} \mathrm{M} \mathrm{KIO}_{3}$. To this mixture $3 \mathrm{ml}$ aliquot of CPZ solution is added and the mixture is rendered acidic by the addition of $1.000 \mathrm{ml}$ of 1.000 $\mathrm{M} \mathrm{HCl}(11.8 \mathrm{~N})$. The mixture is then diluted and the value of absorbance is measured at $526 \mathrm{~nm}$ after letting the mixture to stand for 15 minutes in the dark.

\section{Application to various dosage forms}

A portion equivalent to $0.1075 \mathrm{gm}$ of a homogenized powder of 10 tablets Largactil (Aubrey Pharmaceutical Industries - Aleppo/Syria with distinction from the company Avnitis - France $25 \mathrm{mg} / \mathrm{tablet}$ ) was weighed and dissolved in $100 \mathrm{ml}$ water. Dissolution of the drug was assisted by means of magnetic stirring and an ultrasonic bath. The resulted solution was cleaned through a Whatman filter paper No.1. and the volume was made up to the dent with distilled water in $100 \mathrm{ml}$ calibrated flask. The drug gratified of an aliquot of this solution was found by applying the general procedure as pronounced above.

\section{Results and Discussion:}

When CPZ was treated according to the recommended procedure, the recorded absorption spectrum of the formed reaction product for the range of 450 to $600 \mathrm{~nm}$ against reagent blank shows an extreme absorption at $526 \mathrm{~nm}$, while, the blank does not have any significant absorbance in this region, as it is shown in (Fig.2).

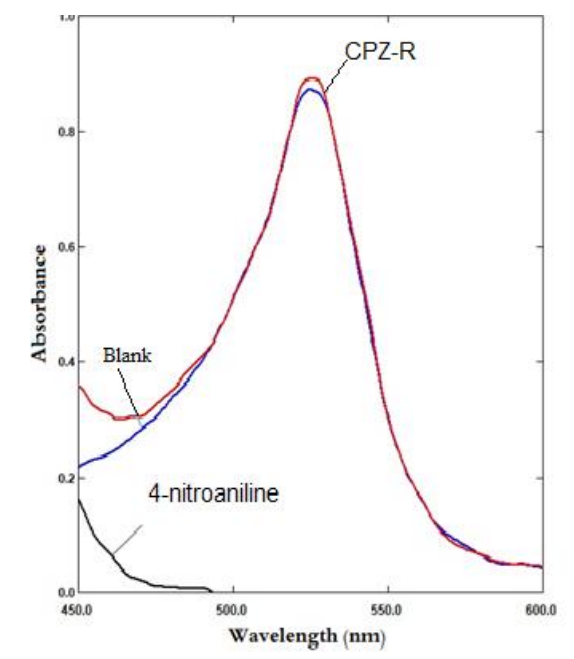

Figure 2. The absorption spectra of $30 \mu \mathrm{g} / \mathrm{ml} \mathrm{CPZ-} \mathrm{R}$ coupling product against reagent blank solution, 30 $\mu \mathrm{g} / \mathrm{ml}$ CPZ $-\mathrm{R}$ coupling product against distilled water, and reagent blank solution against distilled water.

\section{Optimization of reaction conditions:}

The effect of the amount of $\mathrm{HCl}$, 4-nitroanilline, and potassium periodate was investigated. The results show that use of $1.000 \mathrm{ml}$ of $1.000 \mathrm{M}$ hydrochloric acid (i.e. $\mathrm{pH}=2.2$ ) with $1.500 \mathrm{ml}$ of $1.000 \times 10^{-2} \mathrm{M}$ of $\mathrm{KIO}_{3}$, and $1 \mathrm{ml}$ of $1.000 \times 10^{-2} \mathrm{M}$ of coupling reagent give best results (Fig. $3 \mathrm{a}, \mathrm{b}$ and c respectively).

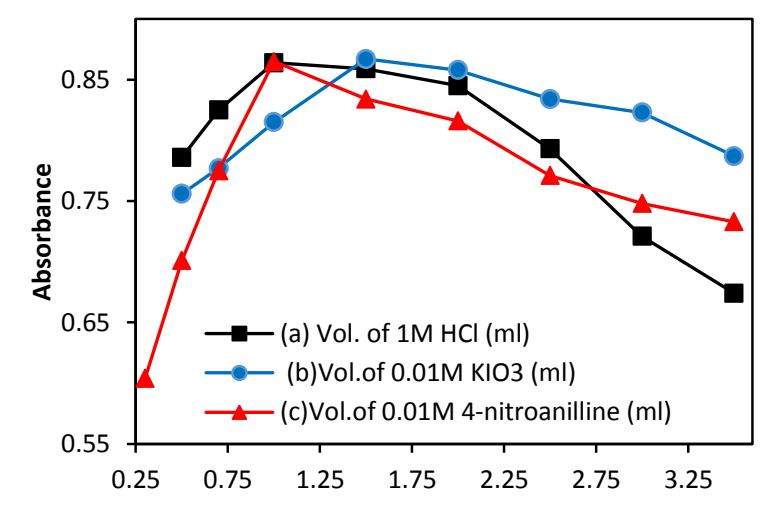

Figure 3. Effect of (a) $\mathrm{HCl}$, (b) $\mathrm{KIO}_{3}$, and (c) 4nitroanaline on the on the formation of the colored product.

The order of addition of the reactants should be followed, as cited in the recommended procedure. Moreover, optimum time for full color development was found to be 10minutes, and room temperature $15 \mathrm{C}^{\circ}$ was found the most favorable for the color development of the reaction product, Fig. 4 ( $\mathrm{a}$ and $\mathrm{b}$ respectively). 


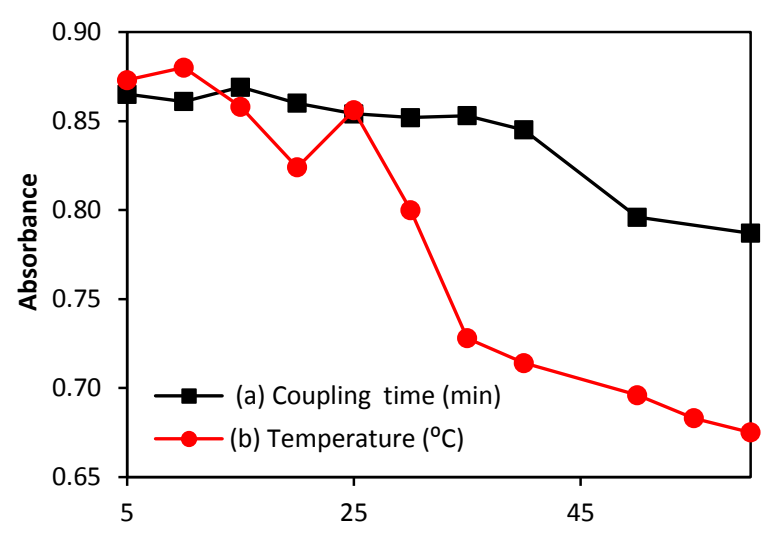

Figure 4. Effect of (a) coupling time, (b) Temperature, on the formation of the colored product.

Furthermore, water was found to be the best solvent among different solvents (viz: water, ethanol, acetone and diethyl ether) tried to solvate the reaction medium and to obtain the perfect absorbance, Fig.5.

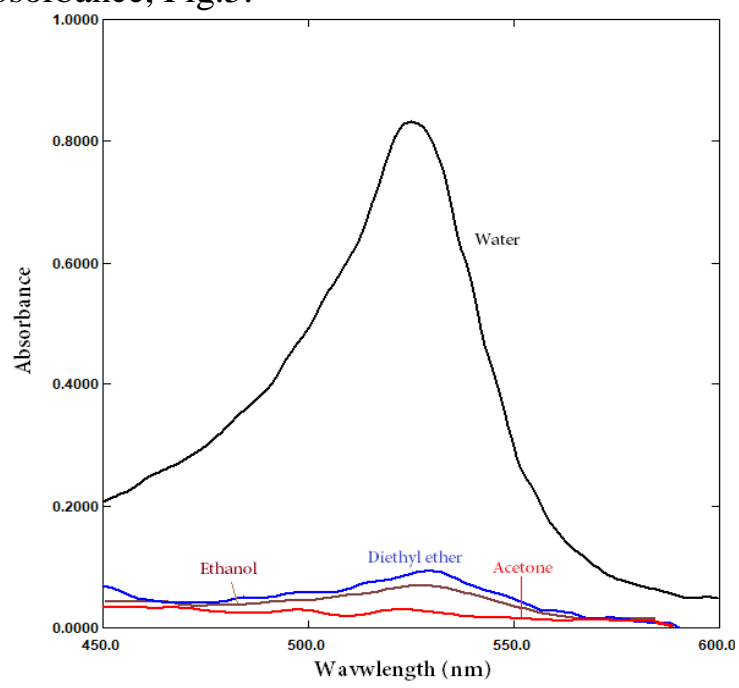

Figure 5. Effect of solvent.

\section{Calibration graph and the statistical data}

Using the obtained optimum conditions, a calibration curve was built (Fig.6). The graph shows that the violet colored product obeys Beer's law in the range of concentration of $5-40 \mu \mathrm{g} / \mathrm{ml}$ of CPZ. Table 1.depicts the statistical information of the calibration curve of spectrophotometric determination of CPZ.

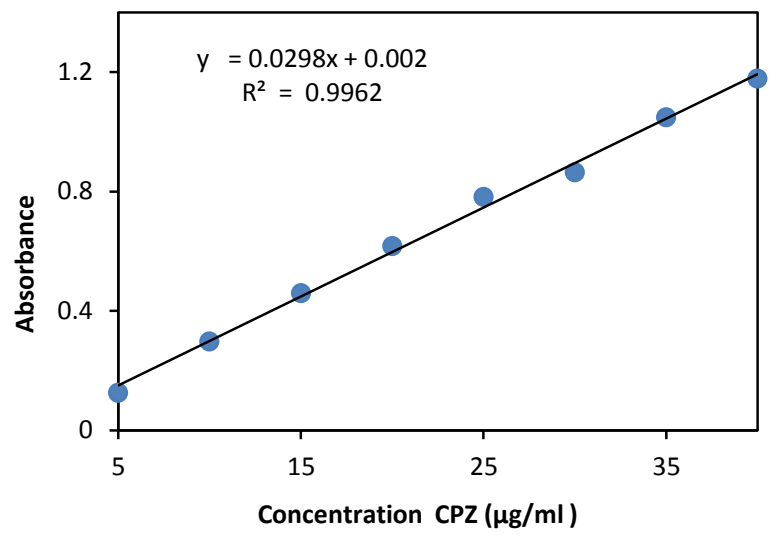

Figure 6. Calibration curve for the determination of chlorpromazine hydrochloride under optimal condition.

Table 1. Statistical data of the calibration curve for the spectrophotometric determination of CPZ.

\begin{tabular}{cc}
\hline Parameter & Value \\
\hline$\lambda_{\max } \mathrm{nm}$ & 526 \\
Color & Violet \\
Linear range $(\mu \mathrm{g} / \mathrm{mL})$ & $5-40$ \\
Regression equation & $\mathrm{A}=0.0298[\mathrm{CPZ}]+$ \\
Molar absorptivity $(\mathrm{L} / \mathrm{mol} . \mathrm{cm})$ & $1.025 \times 10^{4}$ \\
Correlation coefficient & 0.9980 \\
Intercept & 0.002 \\
Slope & 0.0298 \\
$\mathrm{~S}_{\mathrm{b}}$ & 0.0307 \\
$\mathrm{~S}_{\mathrm{a}}$ & 0.197 \\
$\mathrm{LOD}(\mu \mathrm{g} / \mathrm{mL})(18)$ & 0.0930 \\
$\mathrm{LOQ}(\mu \mathrm{g} / \mathrm{mL})(18)$ & 1.03 \\
Sandell's sensitivity $\left(\mu \mathrm{g} / \mathrm{cm}^{2}\right)$ & 0.03467 \\
\hline precision and $\mathrm{Accuracy}$ &
\end{tabular}

precision and Accuracy

The capability of the method was statistically evaluated via measuring accuracy as relative error percentage $\left(\mathrm{E}_{\mathrm{rel}} \%\right)$, and precision as relative standard deviation percent of the proposed methods. Table 2 illustrates that the results obtained for seven replicates at three concentration levels of $\mathrm{CPZ}$ were satisfactory which indicate that the proposed methods have a good precision and accuracy.

Table2. Evaluation of precision and accuracy for determination of $\mathbf{C P Z}$.

\begin{tabular}{ccccc}
\hline \multicolumn{2}{c}{ Conc.of } & $\mathbf{C P Z}(\boldsymbol{\mu g} / \mathbf{m l})$ & \multirow{2}{c}{ E $_{\text {rel\% }}$} & $*$ *RSD \% \\
\cline { 1 - 2 } Taken & Found & & \\
\cline { 1 - 2 } 10 & 10.20 & 2.00 & 1.831 \\
30 & 29.80 & & -0.600 & 0.231 \\
40 & 40.11 & 0.275 & 0.255 \\
\hline$* \mathrm{n}=7$ & & &
\end{tabular}

\section{Stoichiometry of reaction}

The stoichiometry of the response between CPZ and the mixture was investigated using Job's method and mole- ratio method. The consequences 
obtained via the two methods indicate that the stoichiometry of the water-soluble coupling product between drug and the reagent is 1:1 (Fig. 7 and Fig. 8)(15).

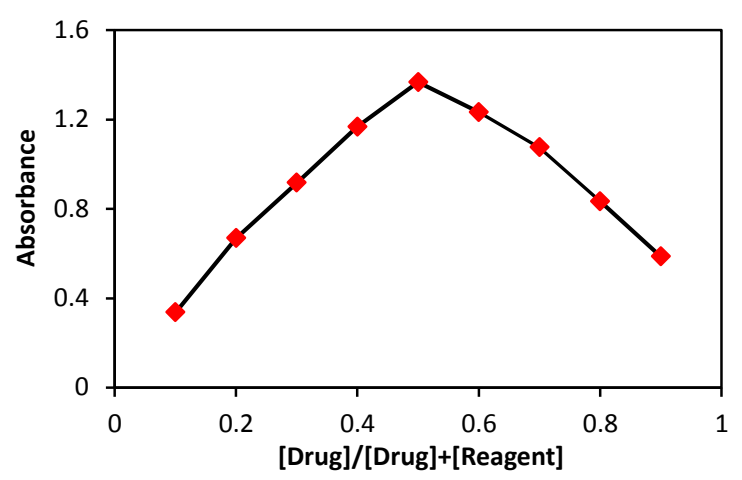

Figure 7. Job's method.

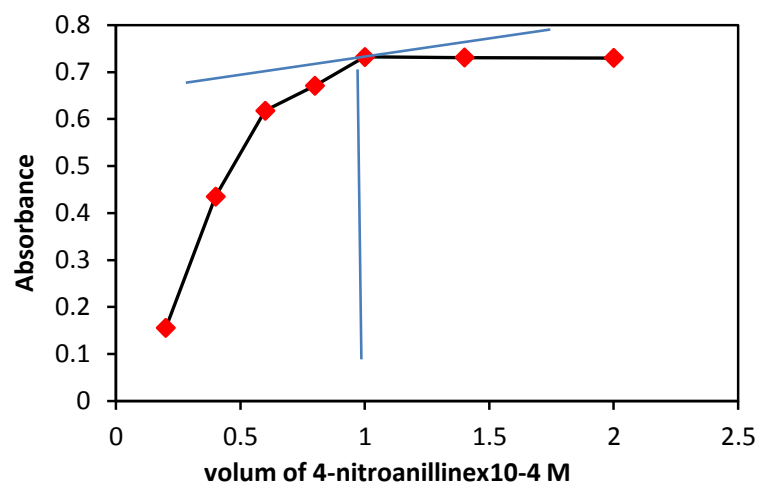

Figure 8. Mole ratio for reaction of $(\mathrm{CPZ})$ with reagent.
Accordingly, a mechanism for formation of the colored product upon the reaction between $\mathrm{CPZ}$ and reagent in presence $\mathrm{KIO}_{3}$ is founded in scheme 1:

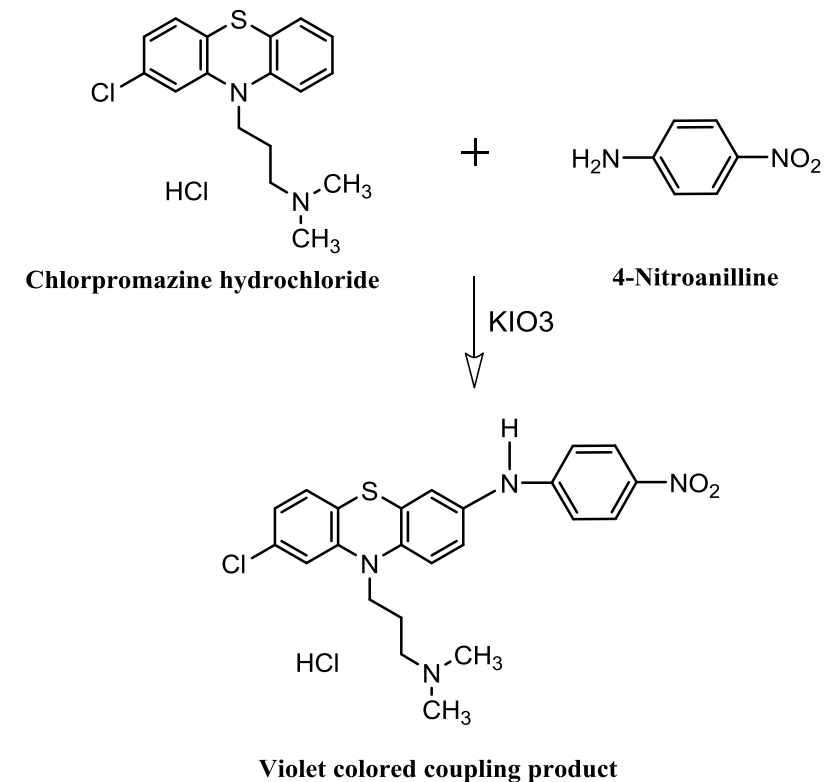

Scheme 1. The suggested mechanism for formation of the colored product.

Analysis of CPZ in pharmaceutical preparations

Two procedures (direct calibration and standard additions) were followed using the proposed method to determine CPZ in Largactil tablets. The obtained results are shown in Table 3 and in Fig.9. Good agreement in results was found for both procedures.

Table 3. Determination CPZ in Largactil Tablets ( $25 \mathrm{mg} / \mathrm{tablet})$, by direct calibration and standard addition method.

\begin{tabular}{|c|c|c|c|c|c|c|c|}
\hline \multirow[t]{2}{*}{ Procedure } & \multicolumn{2}{|c|}{ Conc. of CPZ $(\mu \mathrm{g} / \mathrm{ml})$} & \multirow[t]{2}{*}{$\mathbf{A E}$} & \multirow[t]{2}{*}{ SD } & \multirow[t]{2}{*}{ RSD\% } & \multirow{2}{*}{$\mathrm{E}_{\text {rel }} \%$} & \multirow[t]{2}{*}{ Recovery \% } \\
\hline & Taken & Found & & & & & \\
\hline Direct calibration. & 10 & 10.06 & 0.06 & 1.41 & 0.009 & 0.68 & 100.68 \\
\hline & 40 & 40.27 & 0.27 & 1.45 & 0.360 & 0.675 & 100.675 \\
\hline Standard additions & 25 & 23.94 & -1.06 & 1.42 & 0.589 & -4.219 & 95.780 \\
\hline
\end{tabular}

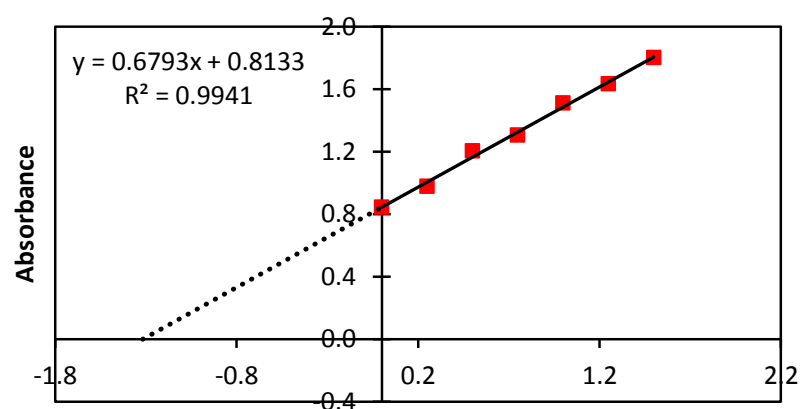

Vol. of $(500 \mu \mathrm{g} / \mathrm{ml}) \mathrm{CPZ}$ solution

Figure 9. Standard additions plot.

\section{Conclusion:}

A rapid, simple and precise spectrophotometric method has been suggested for the determination of chlorpromazine hydrochloride in aqueous solution based on oxidation with 4-nitroanilline and $\mathrm{KIO}_{3}$ in the acidic solution. The suggested method does not require temperature control or the solvent extraction step, the method was applied, successfully for the determined of amounts commercial CPZ drug.

\section{Conflicts of Interest: None.}

\section{References:}

1. Rang HP, Dale MM, Ritter JM, Flower RJ, Henderson GR. Pharmacology. Elsevier Churchill Livingstone; 2012.777p.

2. Rockville RO, The United State Pharmacopeia Inc. 2014. p 3503.

3. British Pharmacopeia; The Requirements of the 7th Ed. of the European Pharmacopoeia; 2013. CD Rom.

4. Saleh TS. Assay of four Psychotropic drugs Chlorpromazine, Amitriptyline and Nortriptyline in 
tablets by Single HPLC method. Int J Pharm Pharm Sci.2016; 8(8):182-188.

5. Usha NU ,Divya KD, Sahithi GS. New validated RPHPLC method for simultaneous estimation of chlorpromazine and trihexyphenidyl $\mathrm{HCl}$ in tablets.ijapa. 2014;4(4):134-137.

6. Khanin VA, Moiseiev OO, Goncharova NB, Kotenko OM. The Study of Degradation Products of Chlorpromazine Hydrochloride by The Method of Liquid-Mass Spectroscopy in Drugs for Injection. IJOQC. 2015;13(3):51-57.

7. Riyadh MJ, Al-Hitti IK, Adawiya, JH.Potentiometric Sensor for Determination of Chlorpromazine Hydrochloride in Tablets and Urine. KAJ. 2015;Part A-11(1):7-14.

8. Mohamed GG, Frag YZ, Zayed MA, Elashery EA. Fabrication of chemically and in situ modified carbon paste electrodes for the potentiometric determination of chlorpromazine $\mathrm{HCl}$ in pure pharmaceutical preparations, urine and serum. New J. Chem.2017;41(24): 15612-15624.

9. Al-rashidy AA. Electrochemical methods Voltammetric and Ion-Selective electrode for methyl orang) for determination of drugs Amitriptyline hydrochloride (AMI), Sulfamethoxazole (SMZ) and chlorpromazine hydrochloride $(\mathrm{CPZ})$ in Its Formulations, PhD. Thesis, Tikrit University.2015.

10. Venkatachalam PV, Shetti1 AS. LC-MS/MS Determination of Trihexaphenydyl $\mathrm{HCl}$, Trifluoperazine $\mathrm{HCl}$ and Chlorpromazine $\mathrm{HCl}$ from Blood Plasma.JPBMA.2011; 9(9):1-10.

11. Fonseca BM, Moreno IB, Costa SB. Determination of seven selected antipsychotic drugs in human plasma using microextraction in packed sorbent and gas chromatography--tandem mass spectrometry. ABCJ. 2013;405:3953-3963.

12. Hijran SJ, Azad TF. Flow Injection Analysis with Chemiluminescence detection for Determination of Two Phenothiazines. IJPSR .Mar 2015; 6(3):474-481.

13. Shakir IM, Hamzeh MJ. New approach development for determination of chlorpromazine $\mathrm{HCl}$ in pure and pharmaceutical forms using homemade wave length selector flow injection photometer. KJPS. 2012;3(1):86-97.

14. Al Shatti LA. Method Development and Validation of Assay of Chlorpromazine Hydrochloride Tablet Formulation Using Ultra Violet Visible Spectrophotometry. J Anal Bioanal Tech. 2014;5(2):1-4.

Dikran BS, Mohammed KA, Hammodi AS. Spectrophotometric Determination of Chlorpromazine $\mathrm{HCl}$ Using Potassium Permanganate. J. for Pure \& Appl. Sci. 2015;28(1):101-112.

15. Sarah MS, Kasim HK. Spectrophotometric Determination of Chlorpromazine Hydrochloride in Pure and Pharmaceutical formulation by Using The Organic Reagent 2-5 dimethoxyaniline.RJPBCS. 2016;7(5):640-641.

16. Ahmed AK, Baker MH, Hussein N. Spectrophotometric Determination of Chlorpromazine $\mathrm{HCl}$ by Oxidative Coupling Method in Pharmaceutical formulations. TJPS. 2017;22(6):65-71.

17. Dhahir SA, Mohmmed NJ, Narren SF. Spectrophotometric Determination of Carbofuran with Diazotized Benzidine in Environmental Water Samples. BSJ. 2016;13(3):498-510.

\section{التقدير الطيفي لعقار كلوبرومازين هياروكلوريد باستخذام 4-نايترو انلين بوساطة تفاعل الاقتران بالاكسدة}

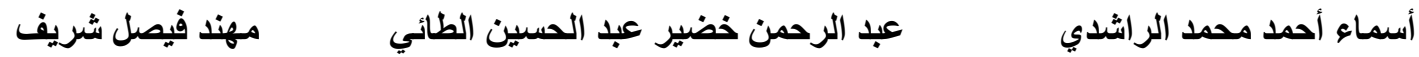

$$
\begin{aligned}
& \text { قسم الكيمياء، كلية التربية للعلوم الصرفة، جامعة تكريت، تكريت، العراق }
\end{aligned}
$$

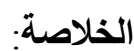

تم تطوير طريقة طيفية بسيطة و سريعة لتقدير عقار كلوبرمازين هيدروكلوريد بشكله الحر وفي بعض مستحضر اته الصيدلانية الطريقة

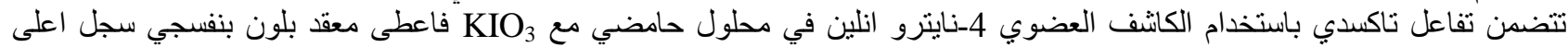

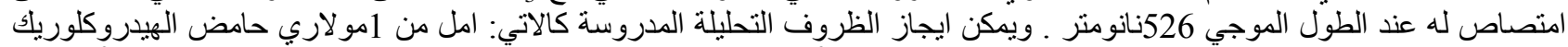

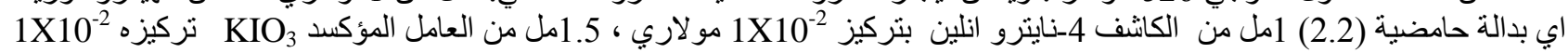

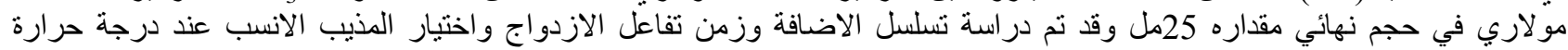

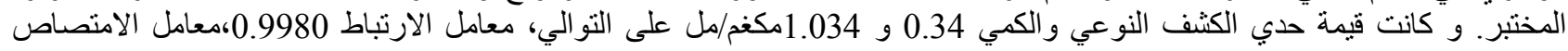

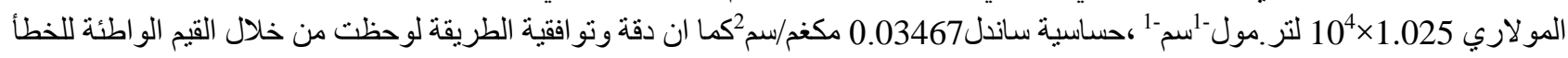

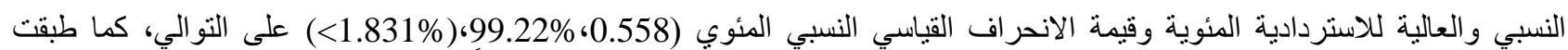

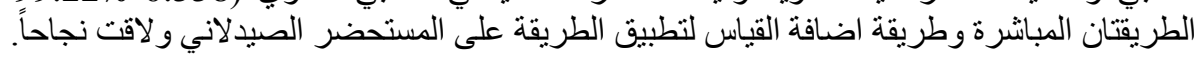
الكلمات المفتاحية: المطيافية، تقدير،4-نايترو انلين، هيدروكلوريد الكلوبرومازين،
} 